\title{
Ethical differentiation and market behavior: An experimental approach
}

\author{
Julian Rode, ${ }^{*}$ Robin M. Hogarth, ${ }^{*}$ Marc Le Menestrel** \\ julian.rode@upf.edu \\ robin.hogarth@upf.edu \\ marc.lemenestrel@upf.edu
}

May 2006

\footnotetext{
* Universitat Pompeu Fabra, Barcelona.

* ICREA and Universitat Pompeu Fabra, Barcelona.

- The authors gratefully acknowledge the financial assistance of the DAAD (Deutsche Akademische Austauschdienst) (Rode) and the Spanish Ministerio de Educación y Ciencia (Hogarth). They also thank Rosemarie Nagel, Jaume Garcia, Andreas Ortmann, Matthew Ellman and the referees for their constructive comments. For correspondence, please contact Robin M. Hogarth, Universitat Pompeu Fabra, Department of Economics \& Business, Ramon Trias Fargas 25-27, 08005 Barcelona, Spain. Tel: (34) 935422561.
} 


\begin{abstract}
Does ethical differentiation of products affect market behavior? We examined this issue in triopolistic experimental markets where producers set prices. One producer's costs were higher than the others. In two treatments, the additional costs were attributed to compliance with ethical guidelines. In the third, no justification was provided. Many participants playing the role of consumers reduced their experimental gains by purchasing the ethically differentiated product at a higher price - whether or not they knew the amount of extra cost. Individual differences were important (students of business/economics paid smaller premia than others). Finally, we speculate about the observed "demand function" for ethics and emphasize the use of experimental methodology to complement empirical studies designed to assess the potential market for ethically differentiated products.
\end{abstract}

Keywords: Fair trade; ethical premia; price competition; contextual effects.

JEL classification: A13, B41, D43, D46. 
In recent years, an increasing number of firms have started to signal that their products are produced under "fair" conditions (e.g., no child labor or no exploitation of agricultural workers). In 2002, for example, the total market for such "ethical consumption" was estimated at $£ 19.9$ billion in the UK alone (Cooperative Bank, 2003). In the EU and the USA, fair trade organizations reported increases in sales of labeled products for 2003 over 2002 that varied between $42 \%$ and $91 \%$. Moreover, similar growth rates have been observed for several years (for data see FLO, 2005 and TransfairUSA, 2004).

Prices of fair trade products are typically higher than those of the substantially equivalent products with which they compete in the marketplace. And yet, there is little empirical evidence about the conditions under which consumers are prepared to pay higher prices, i.e., "ethical premia." In discussing the role of ethics in the market place, Shleifer (2004) uses the example of child labor stating that "if public opinion really turns against child labor, firms that do not hire children will be able to charge higher prices" (p. 417). Knowing when, and to what degree such shifts in preferences occur is clearly an important practical issue.

Several surveys have already estimated consumers' willingness to pay for ethical products $^{1}$ (see, e.g., Pelsmacker, Driesen \& Ryap, 2003). These data are hypothetical and represent attitudes that may or may not result in purchases. Thus, it is legitimate to question whether they generalize to market behavior (Carrigan \& Atalla, 2001; Tallontire, Rentsendorj \& Blowfield, 2001). In addition, although econometric studies using market data are more credible (cf., Bjorner, Hansen \& Russell, 2004), they are subject to market frictions (e.g., limited distribution to special stores, lack of consumer information) and the variability that consumers face in observed ethical premia is limited.

\footnotetext{
${ }^{1}$ We use the term "ethical" in a broad sense to cover considerations of so-called "fair trade" and more specific issues such as labor standards, discrimination, and the like.
} 
Recently, some researchers have used field experiments as a methodology to overcome these problems. Anderson and Hanson (2004) report an experiment conducted at two Home Depot stores in Oregon, where "ecolabeled" and unlabeled plywood products were sold side by side. They found that the labeled version of the product accounted for $37 \%$ of all sales when priced at a premium of $2 \%$. Kimeldorf et al. (2006) use a "good working conditions" label to differentiate otherwise equivalent sport socks in a department store in Michigan. They show that, even at a price premium of $40 \%$, nearly a quarter of sales are from the labeled version of the product. They further show that the share of "ethical" sales is sensitive to changes in the size of the premium. While field experiments have the advantage of unambiguously testing "true" purchasing actions in the presence of a labeled product, they also face serious difficulties. For instance, as the authors of both studies point out, consumer information about the label is difficult to assure in a field setting. ${ }^{2}$ In addition, field studies cannot control for sample selection since customers may seek or avoid the choice between labeled and non-labeled versions of a product.

The purpose of this paper is to apply the methodology of experimental economics to assess how much consumers are prepared to pay for "ethically produced" goods and thereby complement evidence from field studies. The principal advantages are that tradeoffs between ethical values and monetary incentives are measured by consumers' choices in controlled settings, and that all participants have to make these decisions under conditions of sufficient and equal information. More specifically, we constructed a triopolistic experimental market environment with fixed demand and posted-offer pricing, where three producers and six consumers interacted in a finitely repeated trading sequence. We chose oligopolistic price competition for its simplicity and close resemblance to commonly observed retail markets. Experimental studies of such price competition confirm theoretical Bertrand predictions for three or more producers (Fouraker \& Siegel, 1963; Dufwenberg \& Gneezy, 2000). With this

\footnotetext{
${ }^{2}$ Interviews in the sport socks study revealed that more than half of all consumers either did not notice or did not
} 
design, we sought to observe producers' pricing behavior and consumers' purchases when an ethical dimension is at play. We introduced an asymmetry in production costs, as done by Gneezy and Nagel (2001) for a comparison of symmetric and asymmetric cost in duopoly markets, but explicitly linked this to an ethical issue. For consumers, the ethical issue was that one firm's products were differentiated as involving no child labor. This was made operational by donating the amount of extra costs to an NGO fighting child labor. Moreover, experimental participants observed these payments being made on-line by internet.

We observed frequent premia for the ethically differentiated version of the product in the experimental markets. Our results showed that many consumers paid ethical premia of different sizes, thereby reducing their monetary gains. Ethical producers recovered profits per unit similar to other producers. Moreover, if consumers lacked explicit knowledge of costs incurred by producers to meet ethical standards, they still paid a premium for ethically produced goods. At the same time, we noted the importance of individual differences (students of business and economics were less willing to pay ethical premia than those from other social sciences and the humanities). We further demonstrated that willingness-to-pay as measured by attitudes was significantly lower for consumers who had previously participated in an ethical market session as opposed to those who had not. This has important implications for the use of surveys in determining the potential size of markets for ethical goods.

Our use of experimentation is in line with recent developments in experimental methodology, which propagates the use of context in experimental instructions when this is relevant to the research question (Harrison \& List, 2004, p.1028; Hogarth, 2005; Cooper, Kagel, Lo, \& Gu, 1999). In the present investigation, we are asking what happens in a market situation when a specific kind of label is attached to a product. In our case of an ethical label, economic actors are faced with tradeoffs between ethical values and changes in their monetary gains. As such, manipulation of context is essential to our experimental design. 
Finally, we note that the importance of similar contextual effects has been recognized for some time in the related field of behavioral decision making (see, e.g., Einhorn \& Hogarth, 1981; Kahneman \& Tversky, 2000; Slovic, Finucane, Peters \& MacGregor, 2002).

\section{Experimental design}

In the experiment, three producers and six consumers exchanged units of a product during 15 periods. In each period, producers first simultaneously posted their prices per unit. Subsequently, consumers purchased the product simultaneously. Consumers had to buy three units in each period, but they were free to choose from which producer(s) they wanted to buy. After each period, producers received the full history of prices and sales. Hence, each experimental session involved 15 periods of a triopolistic experimental market with a fixed demand of 18 units per period, i.e., 270 units per experimental session. Consumers were allocated a fixed budget of 300 ECU (Experimental Currency Units) per period and kept the money unspent. Two producers, A and B, incurred production costs of 20 ECU per unit. Producer C had a production cost of 25 ECU. Producers were free to choose a price between their cost of production (the minimum) and a maximum of 100 ECU. For every unit sold, producers' profits were the difference between their price and production cost.

We ran three treatments. Treatments 1 and 2 were meant to create an experimental analogue to ethical differentiation as experienced in the marketplace. In these treatments, producers were described as international firms whose production facilities were in regions where child labor was prevalent. Producer C was said to comply with the conditions of an internationally recognized NGO fighting child labor. ${ }^{3}$ We provided details of the NGO's activities and the conditions necessary for use of its label. Meeting these requirements, however, implied an increase in production costs. Producer $\mathrm{C}$ thus incurred an additional cost

\footnotetext{
${ }^{3}$ This was part of the hypothetical market frame. Participants knew that producers were randomly assigned by us to play the role of producer $\mathrm{A}, \mathrm{B}$, or C.
} 
per unit. On the screen, Producer C was labeled with an asterisk (*). Participants were further informed that, for every unit sold by Producer $\mathrm{C}^{*}$, a donation equal to the additional production cost would be paid to an NGO fighting child labor (the specific industry in which the NGO operates was not revealed). At the end of each experimental session, the accumulated ethical contributions were transferred on-line to the NGO in the presence of the participants (cf., Eckel \& Grossman, 1996). Hence, by providing specific ethical reasons for the additional costs and by linking purchasing decisions to real donations, we created an ethical differentiation. When Producer $C^{*}$ was not the cheapest, consumers faced a trade-off between wealth and ethics.

In treatment 1 - labeled "ethical differentiation - extra cost known" - consumers knew that the amount of extra cost incurred by producer $\mathrm{C}^{*}$ for complying with the NGO's standard was 5 ECU. In treatment 2 - labeled "ethical differentiation - extra cost unknown" consumers were aware that producer $C^{*}$ incurred extra costs, but did not know the amount. For both treatments we conducted six experimental sessions with 54 participants (i.e., a total of 108 participants).

Treatment 3 was a control condition with "pure cost differentiation - extra cost known". Here, the instructions simply stated that producers were three international firms competing in a market, and that producer $\mathrm{C}$ incurred production costs that were $5 \mathrm{ECU}$ per unit higher than those of $\mathrm{A}$ and $\mathrm{B}$. Thus, in this control treatment no reason was provided for the extra production cost. Six sessions were run with 54 participants.

Treatment 1 served as a benchmark. We gave consumers as much information as possible. In treatment 2 we wanted to approximate the more natural setting where the amount of extra production costs is unknown. The goal of treatment 3 (pure cost differentiation) was simply to test whether results in treatments 1 and 2 could be attributed to the ethical dimension. 
The experiments were conducted in the Experimental Economics Laboratory at Pompeu Fabra University. Subjects were undergraduate volunteers from various fields of study (mostly economics, business, humanities, political sciences). A session lasted between sixty and ninety minutes. This included completing a post-experimental questionnaire. Participants earned on average $€ 8.06$ plus a show-up fee of $€ 5$. At the beginning of the experiments, participants were randomly assigned to computers, then the instructions were distributed and also read out aloud. Participants learned their roles when the first screen appeared. They stayed in the same roles throughout the entire session. For further details, see the Appendix.

\section{Results}

Treatment 1: "ethical differentiation - extra cost known." In all six sessions, the average posted price of producer $\mathrm{C}^{*}$ was higher than the average posted price of producers $\mathrm{A}$ and B. Over all six sessions, the average price posted by $\mathrm{C}^{*}$ was $39.8 \mathrm{ECU}$ while the average price posted by producers A and B together was 33.3 ECU. The dynamics of average prices over all six sessions for $\mathrm{C}^{*}$ compared to $\mathrm{A}$ and $\mathrm{B}$ is shown in Figure 1a. In 14 out of 15 periods, producer $\mathrm{C}^{*}$ posted on average higher prices than producers $\mathrm{A}$ and $\mathrm{B}$.

Insert Figure 1 and Table 1 about here

In the upper left section of Table 1 , we show how the prices of $C^{*}$ compared with those of A and B. Producer $C^{*}$ posted the highest price in 64 of the 90 periods $(71 \%)$ and accounted for 195 purchased units (17\% of the total). In 24 periods (27\%), C*'s price lay between that of $\mathrm{A}$ and $\mathrm{B}$, yielding a market share of $25 \%$. When $\mathrm{C}^{*}$ 's price was the lowest, it captured $97 \%$ of the market (but this only occurred in 2 periods). Overall, producer $\mathrm{C}^{*}$ sold $337(21 \%)$ of all units, for which consumers paid an average price of 34.7 ECU. Producers A and B together sold 1,283 units (79\%) at an average price of $26.8 \mathrm{ECU} ; 1,261$ of these units 
(i.e., 98.\%) were purchased at the minimum price posted in the respective periods (not shown in Table 1). In contrast, only 35 of the 337 units sold by producer $C^{*}$ (i.e. 10\%) were purchased at the minimum price.

Treatment 2: "ethical differentiation - extra cost unknown." In five out of six sessions the average price of producer $\mathrm{C}^{*}$ was higher than the average price of $\mathrm{A}$ and $\mathrm{B}$. Over all six sessions, producer $\mathrm{C}^{*}$ posted an average price of $33.93 \mathrm{ECU}$, while producers A and B posted an average price of 24.87 ECU - see Figure $1 \mathrm{~b}$.

As shown in the upper right section of Table $1, \mathrm{C}^{*}$ posted the highest price in 75 periods $(83 \%)$; in these periods he sold $27 \%$ of all units. In 9 periods $\mathrm{C}^{*}$ 's price lay between that of $\mathrm{A}$ and $\mathrm{B}$ and accounted for $28 \%$ of sales. In the 6 periods where $\mathrm{C}^{*}$ 's price was the lowest, he sold 100 of 108 units (92\%). Over all periods, $C^{*}$ sold 510 units (31\%) for which consumers paid an average price of 31.70 ECU. Producers A and B sold a total of 1110 units (69\%) for an average price of $23.60 \mathrm{ECU} ; 1094$ of these units (i.e., 99\%) were purchased at the minimum price posted in the respective periods (not shown in Table 1), whereas only 100 of the 510 units sold by producer $C^{*}$ were purchased at minimum price (i.e., 20\%).

Control treatment: "pure cost differentiation - extra cost known." In all six sessions the average price of producer $\mathrm{C}$ was higher than the average price of $\mathrm{A}$ and $\mathrm{B}$. The high-cost producer $\mathrm{C}$ posted an average price of $41.23 \mathrm{ECU}$, while producers $\mathrm{A}$ and $\mathrm{B}$ posted an average price of 34.56 ECU. As shown in the lower left section of Table 1, C posted the highest price on the market in 61 periods $(68 \%)$, in which he made $2 \%$ of all sales (i.e., 24 of 1098 units). In 15 periods, $\mathrm{C}$ had the intermediate price and sold only 15 units (6\%). In the 14 periods $(16 \%)$ for which he posted the lowest price, he made $79 \%$ of all sales (i.e., 198 of 252 units).

Overall, C sold a total of 237 units (15\%), for which consumers paid an average price of 38.72 ECU. A and B sold a total of 1383 units (85\%) for an average price of $27.30 \mathrm{ECU}$; 
1318 of the units sold by A and B (i.e. 95\%) were purchased for the minimum price posted in the respective periods (not shown in Table 1). Of the 237 units sold by C, 207 (i.e., 87\%) were purchased for the minimum price.

\section{Discussion}

Pricing behavior. We constructed the experiment to reflect an ethical differentiation in a market for an otherwise substantially equivalent product. We suspected that producers incurring extra production costs for an ethical reason would price their product at a premium. Indeed, as noted previously, $\mathrm{C}^{*}$ 's average price was significantly higher in both treatments with ethical differentiation (ethical differentiation - extra cost known: 39.8 ECU for $C^{*}$ vs. 33.3 ECU for $\mathrm{A}$ and $\mathrm{B}, \mathrm{t}=4.13, \mathrm{p}<.01, \mathrm{df}=5$; Wilcoxon Rank Sum test $(\mathrm{WRS}): \mathrm{Z}=-2.2, \mathrm{p}$ $<.05$; ethical differentiation - extra cost unknown: $33.9 \mathrm{ECU}$ for $\mathrm{C}^{*}$ vs. $24.9 \mathrm{ECU}$ for $\mathrm{A}$ and $\mathrm{B}, \mathrm{t}=2.28, \mathrm{p}<.1 ; \mathrm{WRS}: \mathrm{Z}=-2.0, \mathrm{p}<.05)$. In contrast, the difference between the mean premia of $A$ and $B$ is not statistically significant (ethical differentiation - extra cost known: $t=$ $0.52, \mathrm{~ns}, \mathrm{df}=5$; WRS: $\mathrm{Z}=-1.2$, ns; ethical differentiation - extra cost unknown: $\mathrm{t}=0.10, \mathrm{~ns}$, df $=5 ;$ WRS: $\mathrm{Z}=-.1, \mathrm{~ns})$.

The control treatment shows that pure cost differentiation also induced producers to price higher (41.2 ECU for $\mathrm{C}$ and 34.6 ECU for $\mathrm{A}$ and $\mathrm{B} ; \mathrm{t}=2.36 ; \mathrm{p}<.1$; WRS: $\mathrm{Z}=-2.2, \mathrm{p}<$ .05). Thus, it is difficult to disentangle the effects of ethical and cost differentiation on price setting. In any case, the experiments show that producers do not price substantially equivalent products identically. ${ }^{4}$

Purchasing actions. We refer to prices that exceed the minimum posted price as involving positive premia (i.e., premium equals price less minimum price posted in period).

\footnotetext{
${ }^{4}$ As noted previously, both theory and experimental evidence (Fouraker \& Siegel, 1963; Dufwenberg \& Gneezy, 2000) suggest Bertrand outcomes for three producers. Our results deviate significantly from this prediction - see Figure 1. The inelastic demand in our design may contribute to this difference in market outcomes.
} 
For substantially equivalent products, one might expect consumers to buy all units from the lowest price producer, i.e., at a zero premium. We refer to this as the "standard prediction."

Insert Figures 2 through 4 about here

In both treatments with ethical differentiation, purchases from producers $\mathrm{A}$ and $\mathrm{B}$ were largely in line with this prediction. In treatment 1, only 22 of 1283 units (2\%) were sold at prices above the minimum, and 16 out of 1110 units (1\%) in treatment 2. In contrast, consumers paid a premium for 302 of 337 units (90\%) of C*'s version of the good in treatment 1 and for 410 of 510 units $(80 \%)$ in treatment 2, thereby suggesting that these purchases were motivated by ethical considerations. Moreover, in the control treatment with pure cost differentiation, the high-cost firm C sold only 34 of its 237 units (13\%) at a positive premium, compared to 65 of 1383 units (5\%) sold by firms A and B. Figures 2a,b and 3a,b show premia and corresponding market shares for all periods of all six sessions in each of the two ethical differentiation treatments. To be consistent with the standard prediction, all observations should lie either on the horizontal axes (i.e., positive premia imply zero market shares) or on the vertical axes (i.e., positive market shares with zero premia). Across both treatments, for all 360 observations for producers A and B, 337 (94\%) do indeed lie on one of the two axes. In contrast, this is only true for 29 of 180 periods $(16 \%)$ for the ethical firm $C^{*}$. In 151 cases consumers paid positive premia.

In the control treatment with pure cost differentiation, consumer behavior is largely consistent with the standard prediction. For the 90 periods, this is true for 76,73 , and 71 periods for the products of A, B, and C, respectively. The pattern of the data in Figure 4a is similar to that of producers A and B in Figure $4 b$, and not to that of producer $C^{*}$ in Figures $2 a$ and 3a. Consumers do not pay positive premia for a purely cost differentiated product. 
In conclusion, many consumers paid positive premia for ethically differentiated products. Without ethical differentiation, consumers typically purchased at the lowest price, irrespectively of the producers' costs. Interestingly, paying an ethical premium does not require knowledge of the extra costs needed to conform to ethical guidelines. If anything, in our experiments higher premia were paid when such extra production costs were unknown. ${ }^{5}$

Profits and sales from ethical production. The sales figures shown in Table 1 indicate that, across both ethical differentiation treatments, the ethical producer $\mathrm{C}^{*}$ had an overall market share of $26 \%$ (847 of 3,240 units). C*'s average price per unit sold was higher than those of A and B (32.9 vs. 25.3), and the difference between them (7.6 ECU) exceeds the additional 5 ECU production cost paid by $\mathrm{C}^{*}$. Thus, the sales margin per unit is higher for $\mathrm{C}^{*}$. Also, the ethical producer makes more profits than A and B. $\mathrm{C}^{*}$ 's average profits per session are $557 \mathrm{ECU}$, while A and B gain $529 \mathrm{ECU}$ on average. The average donations per session are 353 ECU.

Separating the data for treatments 1 and 2, however, profits and sales are quite different. In the "extra cost known" treatment, $\mathrm{C}^{*}$ 's market share is $21 \%$ with an average sales price per unit sold of $34.7 \mathrm{ECU}$ (vs. 26.8 for A and B). Due to the low market share, $\mathrm{C}^{*}$ in this treatment makes less average profit than producers A and B (545 ECU vs. 724 ECU). In the "extra cost unknown" treatment, $\mathrm{C}^{*}$ 's market share is $31 \%$ with an average sales price per unit sold of $31.7 \mathrm{ECU}$ (vs. 23.6 for A and B), which leads to a higher average profit for $\mathrm{C}^{*}$ (570 ECU vs. $333 \mathrm{ECU}$ ). In accordance with the differences in market share, the average amount of donations in this treatment is higher than in the "extra cost known" treatment (425 ECU vs. 281 ECU).

These figures suggest, almost paradoxically, that ethical firms stand to gain when consumers are ignorant of the costs of compliance with ethical standards. The direction of the

\footnotetext{
5 In the "extra cost unknown" treatment, it seems natural to ask what prior distributions consumers might have had concerning the additional costs incurred by Producer $C^{*}$. Surprisingly, post-experimental questionnaires
} 
difference, however, may be specific to the amount of extra cost that we examined, i.e., 5 ECU.

\section{Ethical purchasing behavior}

Each of the two ethical treatments (i.e., "extra cost known" and "extra cost unknown") with 36 consumers that faced 15 periods of different price constellations provides a data set of 540 purchasing observations. For both treatments, we want to explain the number of units a consumer purchases from the ethical producer in a certain period. By construction of the experiment this is limited to $0,1,2$, or 3 units.

We specify models of the following form

$$
y_{i t}=x_{i t}^{\prime} \beta+u_{i}+e_{i t},
$$

where the index $i$ denotes the different individuals $(i=1, \ldots, 36)$ and $t$ denotes different time periods $(t=1, \ldots, 15)$. The vector $x$ consists of explanatory variables (to be defined below), and the error term differentiates between unobserved individual effects, $u_{i}$, and idiosyncratic errors, $e_{i t}$.

We considered three types of explanatory variables: price, individual characteristics, and time/wealth. To show the effects of price, we included both the ethical premium and the minimum price in each period using the latter to represent the price level. These variables vary across both time and individuals. The only individual variable (codified by a dummy) we considered was whether participants were students of economics/business. To filter out possible primacy effects, we included dummy variables for the "first 3 periods". Last, we included the gain a consumer had already accumulated prior to the purchasing decision (wealth).

revealed that less than two thirds of consumers had such expectations at all. 
Insert Table 2 about here

We tested different specifications of equation (1), the results of which are summarized in Table 2. The standard OLS regression does not use the panel characteristics of the data nor take into account the categorical nature of the dependent variable but can serve as a first approximation. We next performed both fixed effects (FE) and random effects (RE) analyses. We rejected the fixed effects model by testing that there was significant variance in $u$, the individual effects for both data sets $\left(\chi^{2}(1)=289.8\right.$ for "extra cost known"; $\chi^{2}(1)=509.4$ for "extra cost unknown"). For the data from "extra cost known", the Hausman test allows us to reject the null hypothesis that there is correlation between $x$ and $u(p=.36)$. For the data from "extra cost unknown" we cannot reject this hypothesis $(\mathrm{p}=.01)$. However, since we are primarily interested in directional effects and their statistical significance, and since the individual effects are of particular importance to our analysis, we decided to prefer a random effects over a fixed effects specification for both data sets. We next sought to improve model specification by matching distributional assumptions with the count data characteristics of the dependent variable $(0,1,2$, or 3 ethical units, cf. Cameron \& Trivedi, 1998). Specifically, we estimated the Poisson RE and negative binomial RE models and found little difference between their coefficients. Since the negative binomial RE is less restrictive (i.e., allowing for over-dispersion), we deem this model to be the most plausible for these data. In general, the results in Table 2 are remarkably robust across the different specifications.

Price dependence. It is reasonable to assume that higher ethical premia are less likely to be accepted by consumers than lower ones. Indeed, for both treatments this is confirmed in 
our data by the coefficient for the ethical premium variable that is negative and highly significant. ${ }^{6}$

The coefficient for the price level variable tests dependence of purchases on the general price level. This is positive and significant for both treatments and indicates that a given premium is more likely to be accepted at a higher price level. It also raises the issue of whether consumers accept to pay premia based on their absolute value or relative to the price of the regular product. However, this issue requires further research.

Effects of university education. Whereas much evidence exists documenting a relation between type of reasoning and educational discipline (see, e.g., Nisbett, Fong, Lehman \& Cheng, 1987), does training in economics and business affect the paying of ethical premia? Larrick, Morgan and Nisbett (1990) showed important effects across different contexts for economic cost-benefit reasoning (see also, Larrick, Nisbett \& Morgan, 1993); and Frank, Gilovich and Regan (1993) have documented that economics students act less cooperatively in Prisoner Dilemma games. However, it is not clear whether this apparently more selfinterested behavior generalizes to participants' natural environments (see Yezer, Goldfarb \& Poppen, 1996).

Of the 72 undergraduates playing the roles of consumers in our ethical treatments, 45 $(63 \%)$ were students of economics or business and the rest from other fields (law, humanities, and other social sciences). Thus, given that these participants made choices under market conditions, our experiment provides a sharp test of the effects of economics or business training on the payment of ethical premia. The models specified in Table 2 show a significant and negative impact of the relevant dummy variable in both ethical treatments. That is, students of economics or business at Pompeu Fabra University bought less units of an ethically differentiated good than students from other fields of studies. It would, of course, be

\footnotetext{
${ }^{6}$ Out of 439 purchases that involved ethical units, consumers bought all 3, 2, or only 1 unit of the ethical version in 177,54 , and 208 cases, respectively.
} 
interesting to test whether this result generalizes to other student populations. More generally, the finding raises the issue of identifying segments of populations of consumers who are more or less likely to pay ethical premia.

Primacy and wealth effects. One might expect greater prominence of the ethical dimension at the outset of the experiment when the salience of the ethical issue in the instructions is most recent. We test this suspicion by introducing a dummy for the first three periods. Table 2 shows that this does not seem to be the case, since for both treatments coefficients in the OLS regression are not significantly different from zero. We dropped this variable for the other models. Furthermore, greater gains prior to the purchasing action could lead to higher acceptance of ethical premia, in the sense that one can better afford to be ethical at higher wealth levels. Here, the results of our data are ambiguous. While the coefficient in the "extra cost known" treatment is insignificant, it has the expected positive sign and is significant $(\mathrm{p}<.05)$ for all models in the "extra cost unknown" treatment. A possible explanation may be that both wealth and information about production costs can serve as justifications for purchasing actions, but that, when available, cost information is the dominant factor. Only when such information is missing, does wealth influence acceptance of ethical premia.

\section{Willingness-to-pay statements and experienced behavior}

One goal of the present work was to circumvent the attitude-behavior gap that renders questionable willingness-to-pay statements in survey studies. Whereas we could not assess the size of such a gap in our experiments, the post-questionnaire completed by all participants can illuminate the more general role of prior experience in making willingness-to-pay statements. Specifically, we compare such statements between the 36 participants who had acted as consumers in the "ethical differentiation - extra cost known" treatment (henceforth labeled 
"experienced"), and the 36 participants who had acted as consumers in the "pure cost differentiation - extra cost known" control treatment, where no ethical dimension was involved (henceforth labeled "inexperienced"). In the post-questionnaire, the inexperienced were presented with details of the ethical issue and the NGO in the same manner as the instructions for the ethical differentiation treatments of the experiment. Both groups of participants were asked how much more they would be willing to spend for a product that was produced without child labor, and had been certified by the NGO as such, when the corresponding, unlabeled product was priced at $25 \mathrm{ECU}$ and $50 \mathrm{ECU}$, respectively. ${ }^{7}$

The results in Table 3 show large differences between the two groups. For a regular price of 25 (50), experienced participants stated an average acceptable premium of $6.6(6.8)$, much lower than the average acceptable premium of 16.2 (13.2) stated by inexperienced participants. The differences between the means of the two groups are statistically significant $-\mathrm{t}=4.14(2.95), \mathrm{p}<.01(.01)$.

Insert Table 3 about here

These results show the effect of recent behavioral experience on willingness-to-pay statements (a possible "anchoring" effect). They suggest potential bias in surveys that are not grounded in experience. They further support the use of experimentation to minimize the gap between attitudes and behavior.

Finally, the average stated premia for 25 ECU and 50 ECU are similar within both experienced and inexperienced, and the within-group differences are not statistically significant. However, we do not emphasize this result because the data exhibit considerable individual variability.

\footnotetext{
${ }^{7}$ We do not rule out that the extra cost of 5 ECU in the experiment influenced the amounts stated. We used only data from consumers in both "extra cost known" treatments to assure comparability.
} 


\section{Conclusion and implications}

We conducted market experiments to explore the behavior of economic actors when a traded good involves an ethical dimension and when selling the ethically differentiated version of the good implies an increase in production costs. We show that producers price products with higher costs at a premium, and that many consumers accept to pay this premium when it is linked to an ethical differentiation. In our experiments, we also found that consumers pay such premia when they lack knowledge of the amount of extra costs incurred by ethical producers.

The role of individual differences was emphasized by the finding that students of economics and business are less prepared to pay ethical premia than students from other fields. Our work further demonstrates that people with experience in the ethical experimental market state a significantly lower willingness-to-pay than those without such experience.

Our data can be viewed from perspectives of both consumers and firms. Purchasing data can be thought of as illustrating a demand for ethics. The general trend is downward sloping as confirmed by the negative coefficients for the price premium variable of the regression analysis reported in Table 2. Figures $2 \mathrm{a}$ and $3 \mathrm{a}$ show that demand for the ethical good falls rapidly between premia of 0 to approximately 5 and is quite flat thereafter. However, as noted above, our data are marked by important individual differences and it is unclear how the "demand function" might vary for different segments of the population. (See also Carrigan, Szmigin \& Wright, 2004, concerning the "older" market.) Understanding such variation is an important topic for future research. Moreover, we suspect that this could be sensitive to contextual variables that are typically not studied in economic analyses (cf., Hsee \& Rottenstreich, 2004).

As to producers, the existence of distinctive regions of price sensitivity suggests discontinuities in optimal price setting for ethical goods. More specifically, when the general 
price level is close to marginal cost, profit is maximized by posting a large premium thereby obtaining high profit from a small fraction of ethical consumers. In contrast, the ethical producer's optimal premium is zero for higher prices where maximal profits are captured by a large market share. Indeed, this analysis demonstrates the potential of experimental methods to illuminate the consequences of different pricing strategies that would be difficult to examine in field studies characterized by inattentive consumers and noisy data - in particular, in regions involving low premia and high market shares. Firms can, of course, elect to become ethical producers for many reasons. Our work suggests the possibility of assessing the economic consequences of such decisions.

In our experiment, we cannot eliminate the possibility that ethical purchasing behavior was subject to a so-called experimenter effect, that is, participants wanted experimenters to see that they had acted "ethically." Such effects have been documented in dictator-game experiments (Hoffman, McCabe, \& Smith, 1996). However, it is important to note that our experiments differ significantly from dictator games in that they involved repeated market transactions as opposed to single social actions. If indeed there were such experimenter effects, they could go both ways. ${ }^{8}$ In addition, unlike dictator-game experiments, our primary goal was not to identify and separate the contributions of different motivations. Indeed, we strongly suspect that purchasing ethical goods in the presence of others can induce similar social demand effects in the marketplace. Whether, and to what extent ethical purchasing is sensitive to higher and lower levels of social presence is an important question for further research. ${ }^{9}$

As noted at the outset, this work recognizes that contextual variables can play an important role in economic phenomena. Specifically, we introduced one contextual

\footnotetext{
${ }^{8}$ After all, economics students seem to be willing to adhere to an "economic normative" of buying at lowest cost. Indeed, some of our experimental participants explicitly justified their actions using this argument in the postexperimental questionnaire.
} 
modification - concerning ethical differentiation - into an otherwise abstract market setting and observed the consequences. Our use of a specific contextual variable (i.e., ethical product differentiation) was guided by the observation of a specific market phenomenon (the existence of "fair trade"). We do not claim that all contextual variables would have similar impacts. Finally, given the ambiguity of interpreting empirical studies on the market for "ethical" goods, we believe our approach provides a valuable complement for what is becoming an increasingly important issue for both firms and consumers.

\footnotetext{
${ }^{9}$ For effects of social presence on preferences in another context, see List, Berrens, Bohara, and Kerkvliet
} (2004). 


\section{References}

Anderson, R.C. \& Hanson, E.N., 2004. Determining Consumer Preferences for Ecolabeled Forest Products: An Experimental Approach. Journal of Forestry, 102 (4), 28-32.

Bjorner, T.B., Hansen, L.G., \& Russell, C.S., 2004. Environmental labeling and consumers' choice - an empirical analysis of the effect of the Nordic Swan. Journal of Environmental Economics and Management, $\underline{47}$ (3), 411-434.

Cameron, A. C., \& Trivedi, P. K., 1998. Regression analysis of count data. Cambridge, UK: Cambridge University Press.

Carrigan, M., \& Attalla, A., 2001. The myth of the ethical consumer - do ethics matter in purchasing behaviour? Journal of Consumer Marketing, 18 (7), 560-577.

Carrigan, M., Szmigin, I, \& Wright, J., 2004. Shopping for a better world? An interpretive study of the potential for ethical consumption within the older market. Journal of Consumer Marketing, 21 (4), 401-417.

Cooper, D. J., Kagel, J. H., Lo, W., \& Gu, Q. L., 1999. Gaming against managers in incentive systems: Experimental results with Chinese students and Chinese managers. American Economic Review, 89 (4), 781-804.

Cooperative Bank (2003). Ethical Consumerism Report 2003. Available at http://www.neweconomics.org/gen/uploads/tkuggjui2ngnmpvjyyi5hqrw08012004145902.pdf. Accessed November 2005.

Dufwenberg, M., \& Gneezy, U., 2000. Price competition and market concentration: An experimental study. International Journal of Industrial Organization, 18, 7-22.

Eckel, C. C., \& Grossman, P. J., 1996. Altruism in anonymous dictator games. Games and Economic Behavior, 16, 181-191.

Einhorn, H. J., \& Hogarth, R. M., 1981. Behavioral decision theory: Processes of judgment and choice. Annual Review of Psychology, $\underline{32}, 53-88$.

FLO - Fairtrade Labeling Organizations International, 2005. Data available at http://www.fairtrade.net/sites/impact/facts.html. Accessed November 2005.

Fouraker, L., \& Siegel, S., 1963. Bargaining behavior. New York, NY: McGraw-Hill. 
Frank, R.H., Gilovich T. \& Regan, D.T., 1993. Does studying economics inhibit cooperation? Journal of Economic Perspectives, 7 (2), 159-171.

Gneezy, U. \& Nagel, R., 2001. Behavior in symmetric and asymmetric price competition: An experimental study. Mimeo, Universitat Pompeu Fabra.

Harrison, G.W. \& List, J.A., 2004. Field Experiments. Journal of Economic Literature XLII, 1009-1055.

Hoffman, E., McCabe, K., \& Smith, V. L., 1996. Social distance and other-regarding behavior in dictator games. American Economic Review, $\underline{86}$ (3), 653-660.

Hogarth, R. M., 2005. The challenge of representative design in psychology and economics. Journal of Economic Methodology, 12 (2), 253-263.

Hsee, C. K., \& Rottenstreich, Y., 2004. Music, pandas, and muggers: On the affective psychology of value. Journal of Experimental Psychology: General, 133 (1), 23-30.

Kahneman, D., \& Tversky, A. (Eds.), 2000. Choices, values, and frames. Cambridge, UK: Cambridge University Press.

Kimeldorf, H., Meyer, R., Prasad, M. \& Robinson, I. (2006). Consumers with a conscience: Will they pay more? Contexts $\underline{5}$ (1), 24-29.

Larrick, R.P., Morgan, J.N. \& Nisbett, R.E., 1990. Teaching the use of cost-benefit reasoning in everyday life. Psychological Science, 1 (6), 362-370.

Larrick, R.P., Morgan, J.N. \& Nisbett, R.E., 1993. Who uses the cost-benefit rules of choice? Implications for the normative status of microeconomic theory. Organizational Behavior and Human Decision Processes, 56, 331-347.

List, J. A., Berrens, R. P., Bohara, A. K, \& Kerkvliet, J., 2004. Examining the role of social isolation on stated preferences. American Economic Review, 94 (3), 741-752.

Nisbett, R. E., Fong, G. T., Lehman, D. R. \& Cheng, P. W., 1987. Teaching reasoning. Science, $\underline{238}, 625-631$.

Pelsmaker, P., Driesen, L. \& Rayp, G., 2003. Are fair trade labels good business? Ethics and coffee buying intentions. Working Paper, Universiteit Gent. 
Shleifer, A., 2004. Does competition destroy ethical behavior? American Economic Review, 94 (2), 414-418.

Slovic, P., Finucane, M., Peters, E. \& MacGregor, D. G., 2002. The affect heuristic. In T. Gilovitch, D. Griffin \& D. Kahneman (Eds.), Heuristics and biases: The psychology of intuitive judgment. Cambridge, UK: Cambridge University Press, 397-420.

Tallontire, A., Rentsendorj, E. \& Blowfeld, M., 2001. Ethical consumers and ethical trade: A review of current literature. Policy Series 12, Natural Resources Institute, UK.

Transfair USA, 2004. available at http://www.transfairusa.org/content/about/pr 040329.php. Accessed November 2005.

Yezer, M.A., Goldfarb, R.S. \& Poppen P.J., 1996. Does studying economics discourage cooperation? Watch what we do, not what we say or how we play. Journal of Economic Perspectives, $\underline{10}$ (1), 177-186. 
Table 1 -- Unit sales of producers as a function of C's price relative to those of A and B

Extra cost known

\begin{tabular}{|c|c|c|c|}
\hline & \multirow{2}{*}{$\begin{array}{l}\text { Numbers } \\
\text { of periods }\end{array}$} & \multicolumn{2}{|c|}{$\underline{\text { Units sold }}^{*}$} \\
\hline & & $A \& B$ & C \\
\hline $\begin{array}{l}\text { C posts } \\
\text { maximum } \\
\text { price }\end{array}$ & 64 & $\begin{array}{c}957 \\
(59 \%)\end{array}$ & $\begin{array}{c}195 \\
(12 \%)\end{array}$ \\
\hline
\end{tabular}

\begin{tabular}{|c|c|c|c|c|}
\hline \multirow[t]{6}{*}{$\begin{array}{l}\text { Ethical } \\
\text { differentiation }\end{array}$} & $\begin{array}{l}\text { C's price } \\
\text { between } \\
A \text { and } B\end{array}$ & 24 & $\begin{array}{c}325 \\
(20 \%)\end{array}$ & $\begin{array}{c}107 \\
(7 \%)\end{array}$ \\
\hline & $\begin{array}{l}\text { C posts } \\
\text { minimum } \\
\text { price }\end{array}$ & 2 & $\begin{array}{c}1 \\
(0 \%)\end{array}$ & $\begin{array}{c}35 \\
(2 \%)\end{array}$ \\
\hline & & $\underline{90}$ & $\frac{1,283}{(79 \%)}$ & $\underline{337}$ \\
\hline & & $\frac{\text { Numbers }}{\text { of periods }}$ & $\underline{\text { Units }}$ & sold $^{*}$ \\
\hline & & & $A \& B$ & $\underline{\mathrm{C}}$ \\
\hline & $\begin{array}{l}\mathrm{C} \text { posts } \\
\text { maximum } \\
\text { price }\end{array}$ & 61 & $\begin{array}{l}1,074 \\
(66 \%)\end{array}$ & $\begin{array}{c}24 \\
(1 \%)\end{array}$ \\
\hline
\end{tabular}

\section{Pure cost C's price}

differentiation between $A$ and $B$

C posts

minimum
price

\section{Extra cost unknown}

\begin{tabular}{|c|c|c|}
\hline \multirow{2}{*}{$\begin{array}{r}\text { Numbers } \\
\text { of periods }\end{array}$} & \multicolumn{2}{|c|}{$\underline{\text { Units sold }}^{*}$} \\
\hline & $\underline{A \& B}$ & $\underline{\mathrm{C}}$ \\
\hline 75 & $\begin{array}{c}986 \\
(61 \%)\end{array}$ & $\begin{array}{c}364 \\
(22 \%)\end{array}$ \\
\hline 9 & $\begin{array}{l}116 \\
(7 \%)\end{array}$ & $\begin{array}{c}46 \\
(3 \%)\end{array}$ \\
\hline 6 & $\begin{array}{c}8 \\
(0 \%)\end{array}$ & $\begin{array}{c}100 \\
(6 \%)\end{array}$ \\
\hline$\underline{90}$ & $\frac{1,110}{(69 \%)}$ & $\underline{510}$ \\
\hline
\end{tabular}


Table 2 -- Regression models for purchases of ethical units

\begin{tabular}{|c|c|c|c|c|c|}
\hline & $\begin{array}{l}\text { OLS } \\
\text { Regression }\end{array}$ & $\begin{array}{l}\text { FE } \\
\text { Regression }\end{array}$ & $\begin{array}{l}\mathrm{RE} \\
\text { Regression }\end{array}$ & $\begin{array}{l}\text { Poisson RE } \\
\text { Regression }\end{array}$ & $\begin{array}{l}\text { Neg. Binomial RE } \\
\text { Regression }\end{array}$ \\
\hline \multirow{2}{*}{\multicolumn{6}{|c|}{ Treatment 1: "extra cost known" }} \\
\hline & & & & & \\
\hline$\overline{\text { Price level }}$ & $\begin{array}{c}.012 \\
(2.02)^{*}\end{array}$ & $\begin{array}{c}.022 \\
(3.84)^{* *}\end{array}$ & $\begin{array}{c}.021 \\
(3.69)^{* *}\end{array}$ & $\begin{array}{c}.035 \\
(3.38)^{* *}\end{array}$ & $\begin{array}{c}.037 \\
(3.19)^{* *}\end{array}$ \\
\hline $\begin{array}{l}\text { Ethical premium } \\
\text { Individual }\end{array}$ & $\begin{array}{l}-.027 \\
(-7.71)^{* *}\end{array}$ & $\begin{array}{c}-.030 \\
(-9.30)^{* *}\end{array}$ & $\begin{array}{c}-.030 \\
(-9.27)^{* *}\end{array}$ & $\begin{array}{l}-.097 \\
(-9.92)^{* *}\end{array}$ & $\begin{array}{c}-.112 \\
(-9.28)^{* *}\end{array}$ \\
\hline Econ/Business & $\begin{array}{c}-.613 \\
(-6.87)^{\star *}\end{array}$ & & $\begin{array}{l}-.622 \\
(-3.06)^{* *}\end{array}$ & $\begin{array}{l}-.912 \\
(-2.41)^{*}\end{array}$ & $\begin{array}{c}-.888 \\
(-2.42)^{*}\end{array}$ \\
\hline \multicolumn{6}{|l|}{ Other effects: } \\
\hline$\overline{\text { First } 3 \text { Periods }}$ & $\begin{array}{l}.064 \\
(-.44)\end{array}$ & & & & \\
\hline Wealth & $\begin{array}{l}-.004 \\
(-.21)\end{array}$ & & & & \\
\hline Constant & $\begin{array}{l}1.066 \\
(4.63)^{* *}\end{array}$ & $\begin{array}{c}0.423 \\
(2.65)^{\star *}\end{array}$ & $\begin{array}{l}0.872 \\
(3.91)^{* *}\end{array}$ & $\begin{array}{r}0.040 \\
(.10)\end{array}$ & $\begin{array}{l}2.215 \\
(3.83)^{* \star}\end{array}$ \\
\hline $\begin{array}{l}\text { Observations } \\
\text { \# of individuals }\end{array}$ & $\begin{array}{c}540 \\
36\end{array}$ & $\begin{array}{c}540 \\
36\end{array}$ & $\begin{array}{c}540 \\
36\end{array}$ & $\begin{array}{c}540 \\
36\end{array}$ & $\begin{array}{c}540 \\
36\end{array}$ \\
\hline $\begin{array}{l}\text { R-squared } \\
\text { Log Likelihood }\end{array}$ & .161 & .158 & .158 & -461.6 & -456.8 \\
\hline \multicolumn{6}{|c|}{ Treatment 2: "extra cost unknown" } \\
\hline \multicolumn{6}{|l|}{ Price variables: } \\
\hline Price level & $\begin{array}{c}.078 \\
(4.39)^{* *}\end{array}$ & $\begin{array}{c}.113 \\
(7.96)^{* *}\end{array}$ & $\begin{array}{c}.097 \\
(6.62)^{* *}\end{array}$ & $\begin{array}{c}.071 \\
(3.85)^{* *}\end{array}$ & $\begin{array}{c}.071 \\
(3.85)^{* *}\end{array}$ \\
\hline $\begin{array}{l}\text { Ethical premium } \\
\text { Individual }\end{array}$ & $\begin{array}{c}-.047 \\
(-6.81)^{* *}\end{array}$ & $\begin{array}{c}-.055 \\
(-8.44)^{\star \star}\end{array}$ & $\begin{array}{c}-.050 \\
(-7.85)^{\star *}\end{array}$ & $\begin{array}{l}-.089 \\
(-7.06)^{\star *}\end{array}$ & $\begin{array}{c}-.089 \\
(-7.06)^{\star *}\end{array}$ \\
\hline $\begin{array}{l}\text { Econ/Business } \\
\text { Other effects: }\end{array}$ & $\begin{array}{c}-.501 \\
(-5.62)^{\star *}\end{array}$ & & $\begin{array}{c}-.491 \\
(-3.81)^{\star *}\end{array}$ & $\begin{array}{c}-.491 \\
(-1.77)+\end{array}$ & $\begin{array}{c}-.492 \\
(-1.77)_{+}\end{array}$ \\
\hline$\overline{\text { First } 3 \text { Periods }}$ & $\begin{array}{l}-.026 \\
(-0,15)\end{array}$ & & & & \\
\hline Wealth & $\begin{array}{c}.038 \\
(2.00)^{*}\end{array}$ & $\begin{array}{c}.064 \\
(4.94)^{* \star}\end{array}$ & $\begin{array}{c}.054 \\
(3.88)^{* *}\end{array}$ & $\begin{array}{c}.050 \\
(2.68)^{* *}\end{array}$ & $\begin{array}{c}.050 \\
(2.68)^{* *}\end{array}$ \\
\hline Constant & $\begin{array}{l}-.398 \\
(-.81)\end{array}$ & $\begin{array}{l}-1.625 \\
(-3.94)^{* *}\end{array}$ & $\begin{array}{c}-.933 \\
(-2.12)^{*}\end{array}$ & $\begin{array}{l}-1.108 \\
(-1.78)+\end{array}$ & $\begin{array}{c}15.109 \\
(.05)\end{array}$ \\
\hline $\begin{array}{l}\text { Observations } \\
\text { \# of individuals }\end{array}$ & $\begin{array}{c}540 \\
36\end{array}$ & $\begin{array}{c}540 \\
36\end{array}$ & $\begin{array}{c}540 \\
36\end{array}$ & $\begin{array}{c}540 \\
36\end{array}$ & $\begin{array}{c}540 \\
36\end{array}$ \\
\hline $\begin{array}{l}\text { R-squared } \\
\text { Log Likelihood }\end{array}$ & .235 & .260 & .234 & -582.5 & -582.5 \\
\hline $\begin{array}{l}\text { Values of t statis } \\
+ \text { significant at } 1\end{array}$ & $\begin{array}{l}\text { s in parenth } \\
;{ }^{*} \text { significa }\end{array}$ & at $5 \% ;{ }^{* *}$ sig & icant at $1 \%$ & & \\
\hline
\end{tabular}


Table 3 -- Comparisons of willingness to pay:

Experienced vs. Inexperienced

\section{Average acceptable}

premium in

willingness-to-pay

statements

Experienced $(n=36)$

Inexperienced $(\mathrm{n}=36)$
For regular price of

$25 \mathrm{ECU}$

$\underline{50 \mathrm{ECU}}$

6.6

6.8

16.2

13.2 


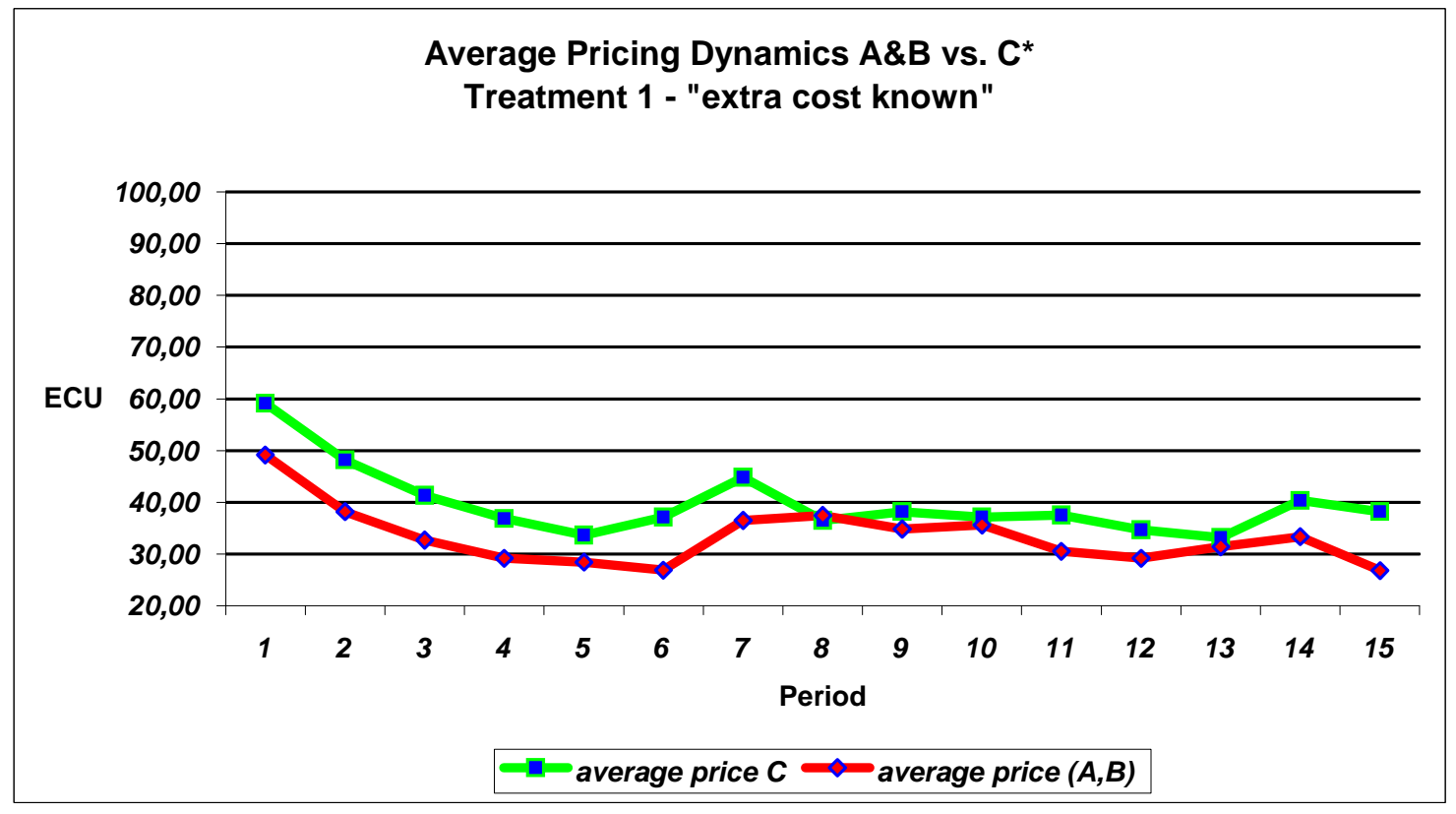

Figure 1a

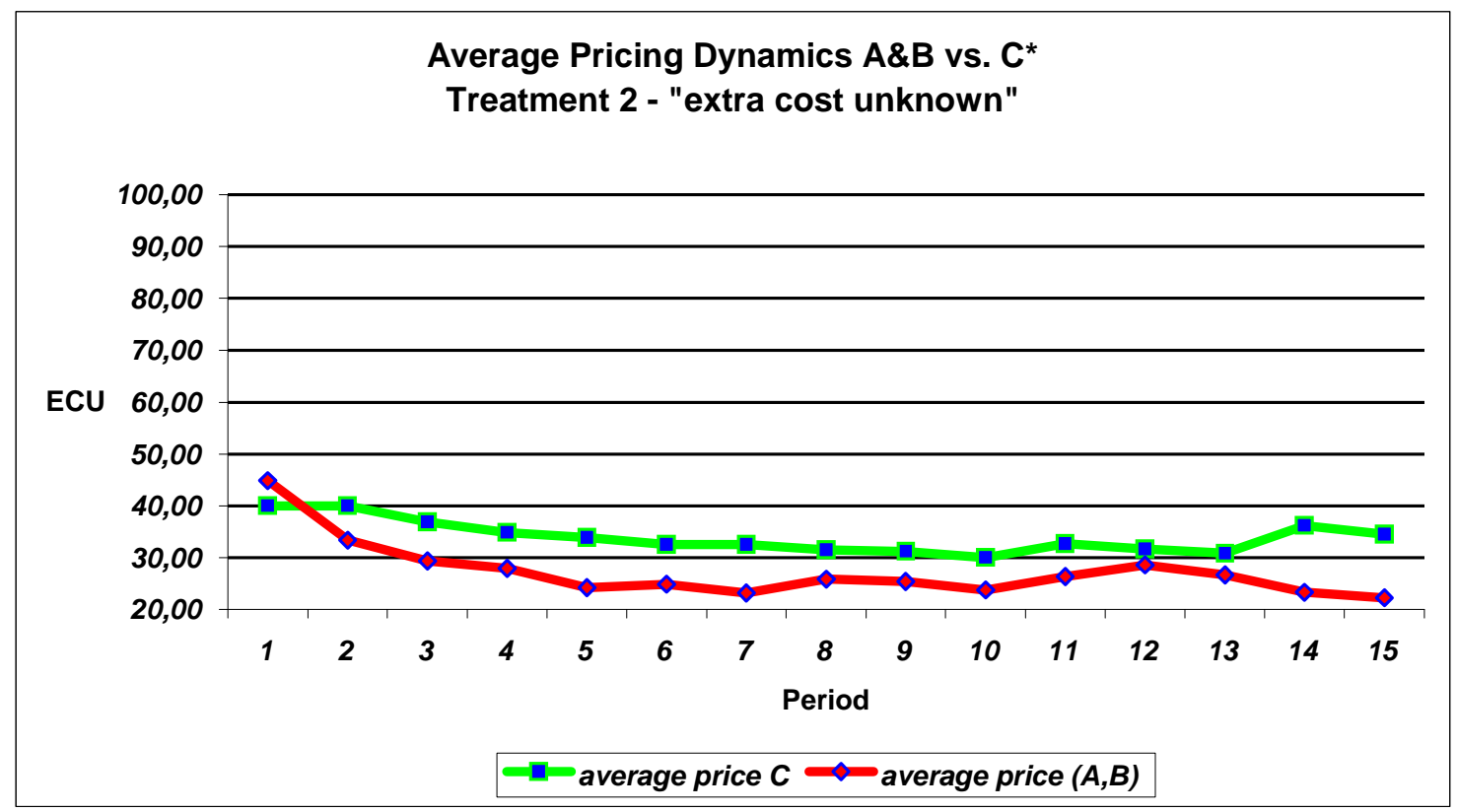

Figure 1b 


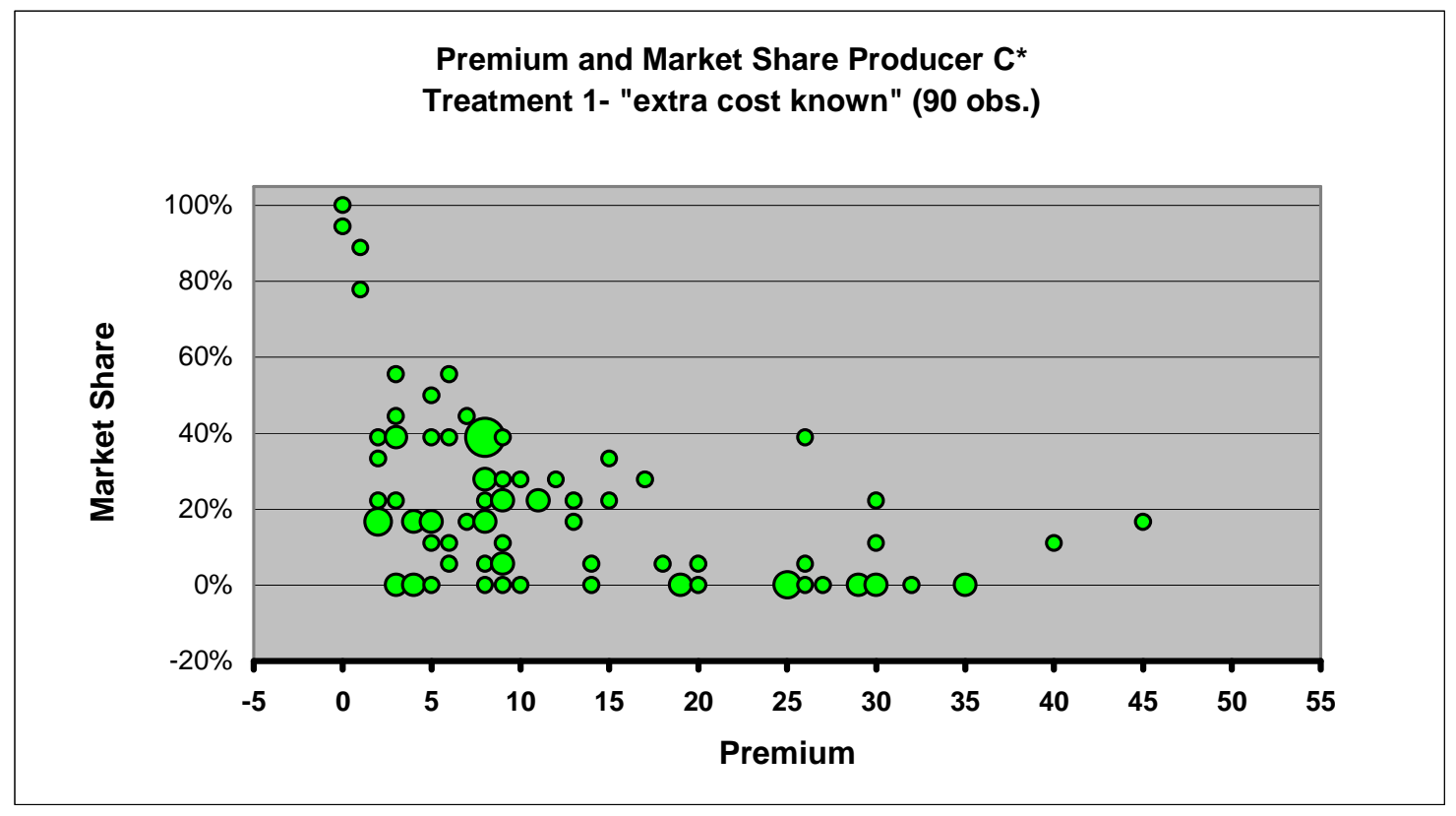

Figure 2a

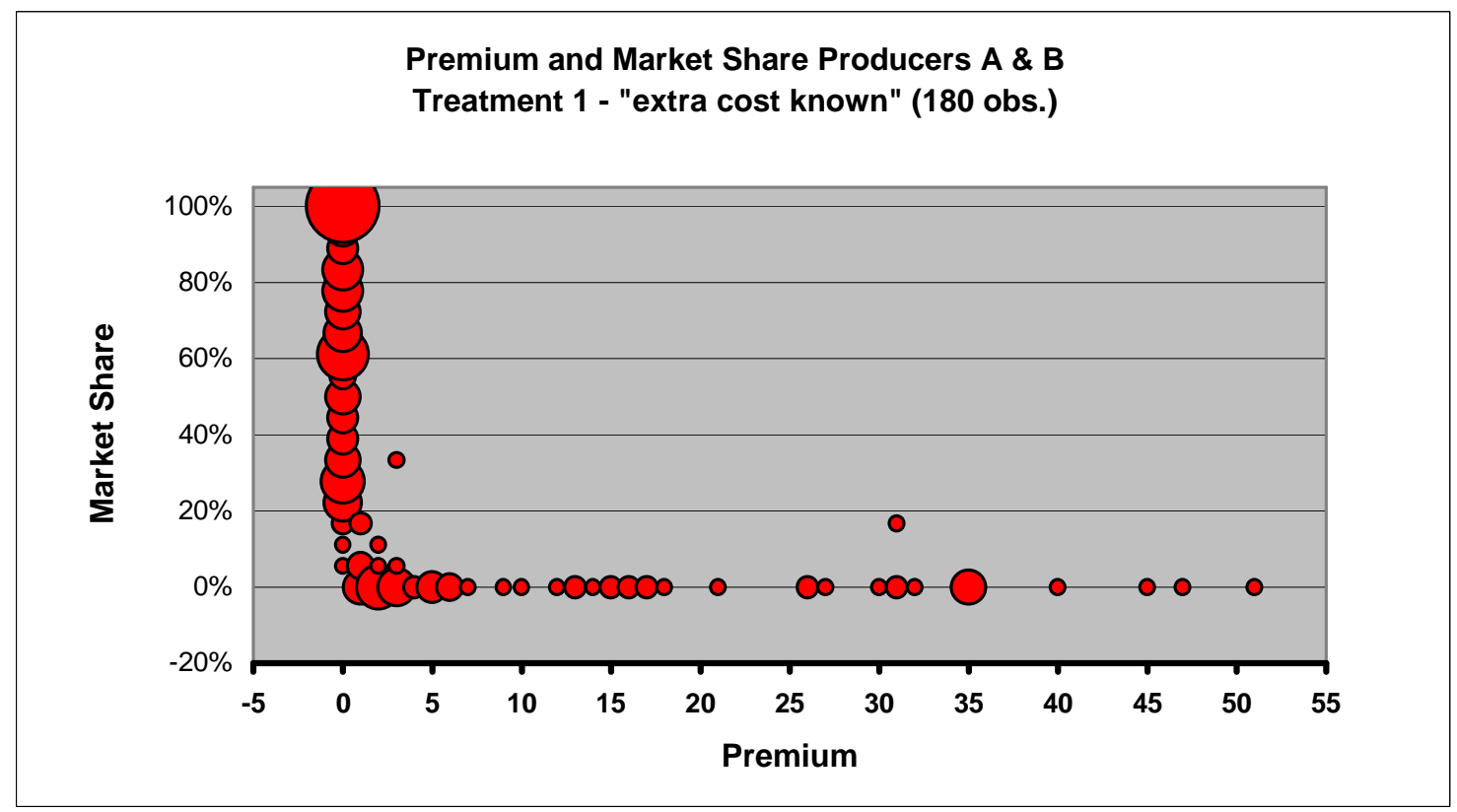

Figure 2b 


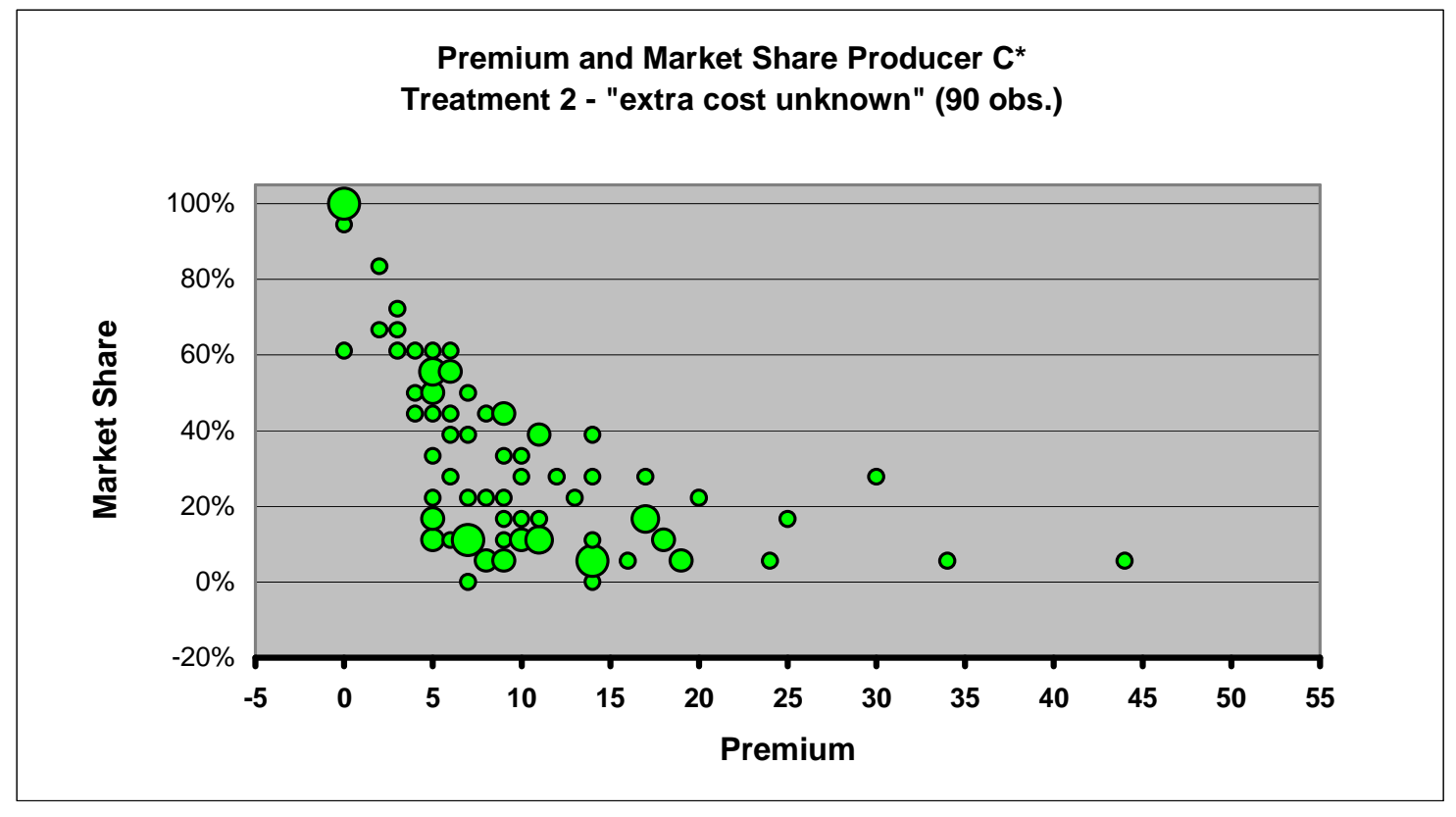

Figure 3a

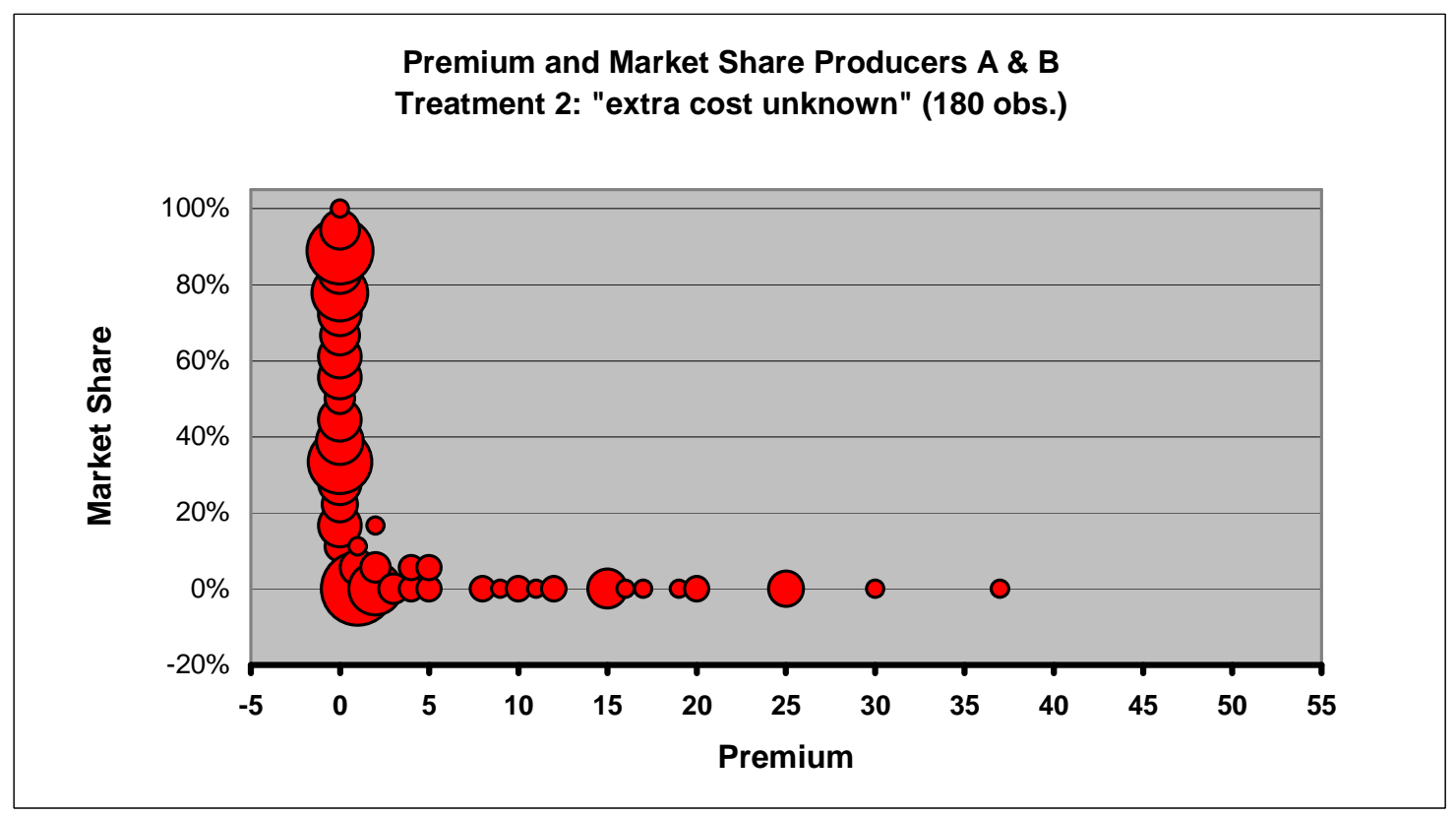

Figure $3 b$ 


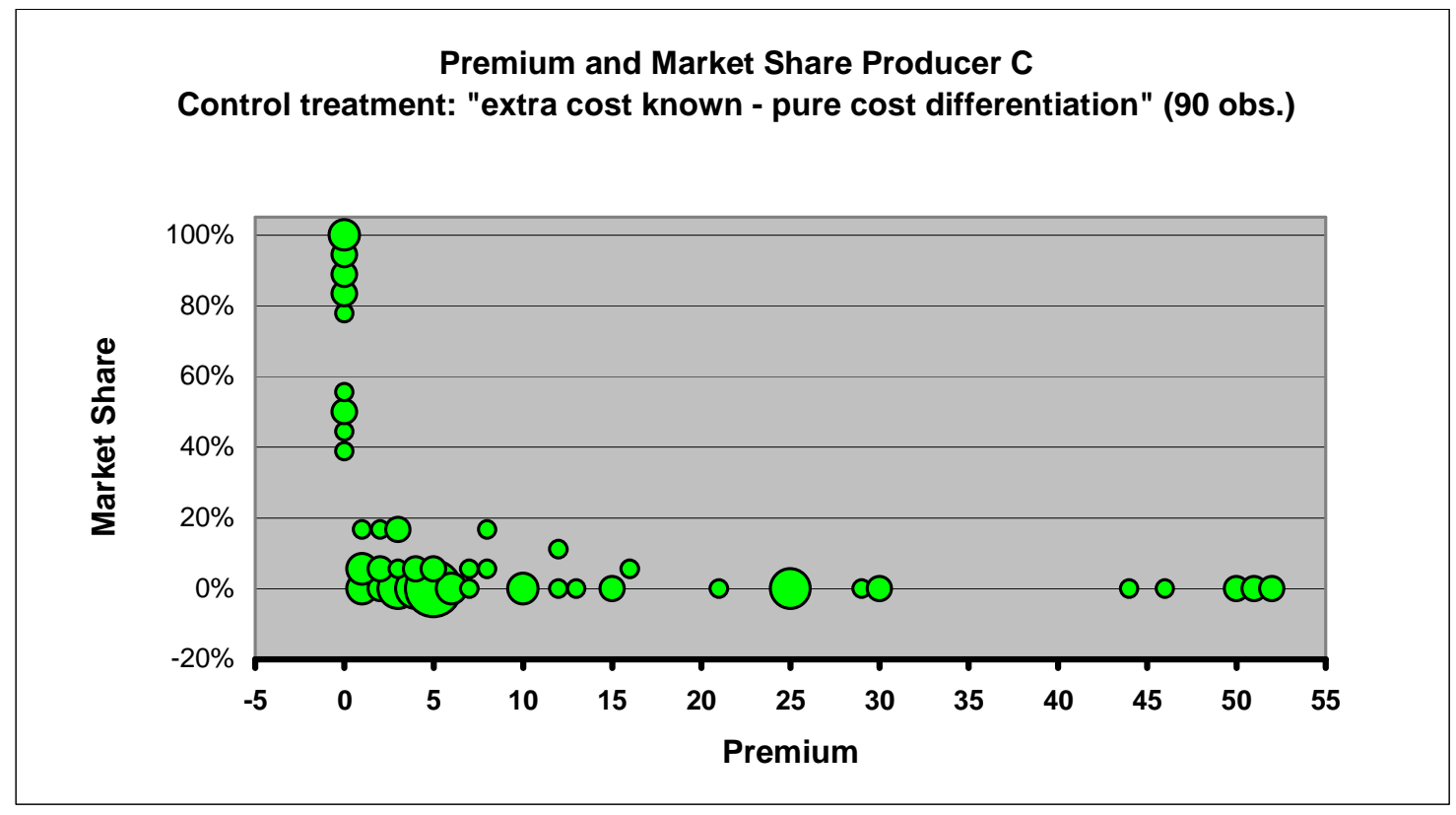

Figure 4a

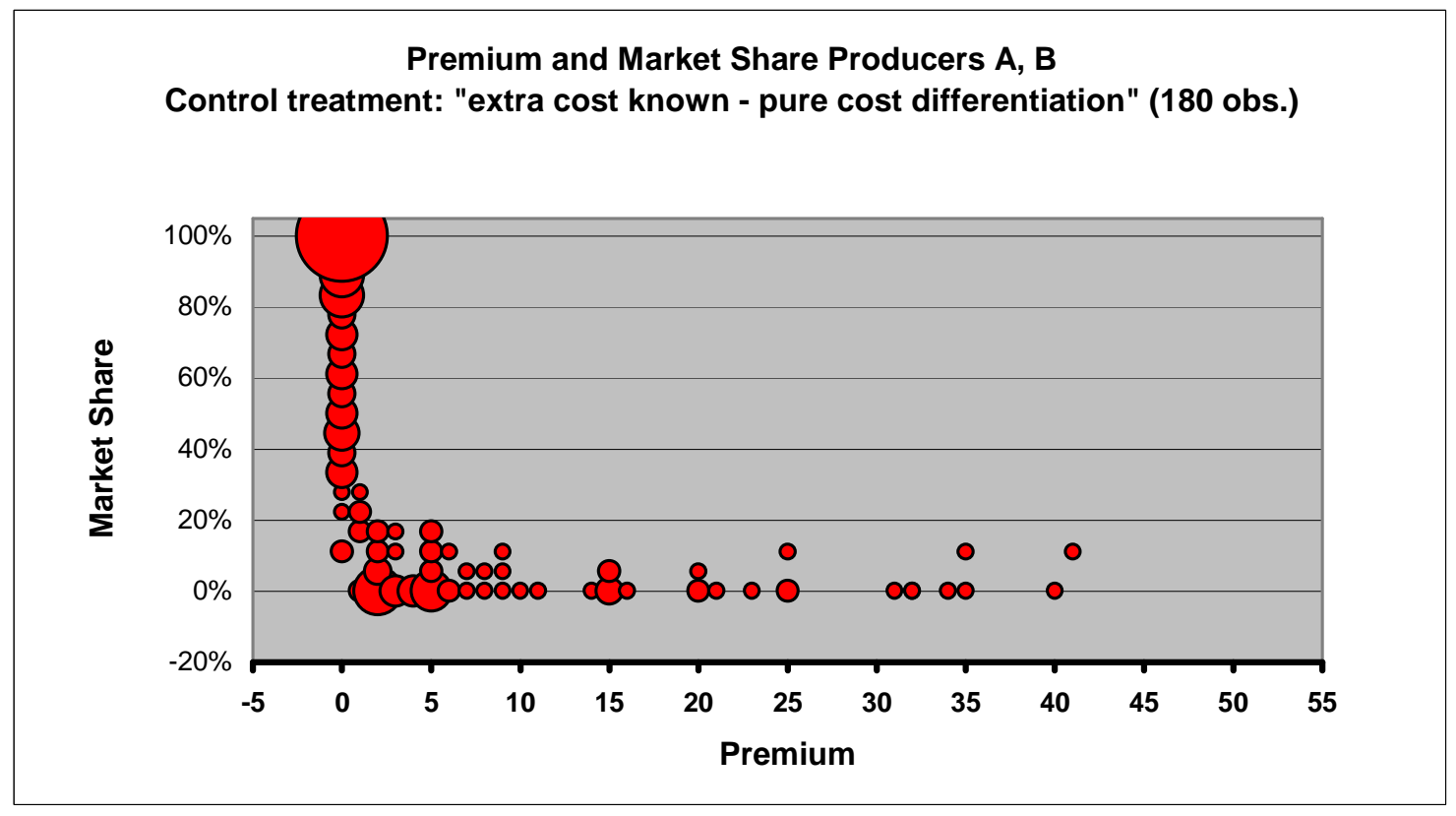

Figure 4b 


\section{Appendix: Instructions Market Experiment}

\section{General Information}

Thank you for participating in this experiment on market decision making, which is part of a research project. Your earnings will depend on your decisions and those of the other participants. As a minimum you will earn a show-up fee of 5 Euros. From now on, we ask you not to talk to each other till the end of the experiment. If you have any question, please raise your hand so that the experimenter can help you. Thank you very much!

You will participate in a market. The market consists of three producers and six consumers. You will be randomly assigned to one of these roles at the beginning of the experiment. You will remain in that role throughout the entire trading sequence, which consists of $\mathbf{1 5}$ periods. You will stay in the same market group with the same participants, but you will never know who they are.

\section{Market Characteristics}

This is a market for one product. Three international firms are competing in this market. It is publicly known that the production of this good is primarily done in India and Pakistan. Although legal regulations against the use of child labor officially exist, the use of various forms of child labor is expected to prevail both in the supply chain and in some final production sites. An internationally recognized NGO named MARK is fighting child labor practices. It offers a label for the product as "child labor free," which on the market will be indicated by a Star-Symbol (*). In the European market, only licensed MARK producers are legally permitted to sell products carrying the MARK label.

To be certified by MARK, producers have to sign a legally binding contract to:

- Abandon any use of child labor in their production sites.

- Hire adult personnel to fair working conditions and standardized wages.

- Allow access to their production sites for unannounced inspections.

MARK provides the following:

- Regular monitoring of production sites by local control committees.

- Organization of schooling projects for previously employed children.

- Education for parents as well as organizational and financial aid to secure the basic needs for directly affected families.

All three producers in the market have been asked to participate in this initiative. However, fulfilling the requirements for the certificate implies an increase in production costs. 


\section{Experimental Procedure}

On the first screen you will see your personal role for the entire experiment. It can be that you have to sell the product as Producer A, Producer B, or Producer $\mathbf{C}$, or to purchase the product as Consumer 1,2,3,4,5 or 6 .

\section{Producers}

- In each period each producer will fix a price for his product simultaneously with the other two producers.

- Producer A and Producer B do not participate in the MARK initiative to fight child labor. Their production costs are 20 ECUs per unit. For each period, Producers A and $B$ must post a price between 20 ECUs and 100 ECUs per unit.

- Producer $\mathbf{C}$ is offering the exact same product, but has agreed to the MARK conditions. Therefore he incurs higher production costs of 25 ECUs per unit. For each period, Producer $C$ must post a price between 25 ECUs and 100 ECUs per unit. As mentioned, Consumer C's product will show a star $\left(^{*}\right)$ symbolizing the MARK label in order for the consumer to distinguish it from producers A and B's products.

- The extra production costs of 5 ECUs (of the 25 ECUs) for each (*) unit sold by Producer $\mathrm{C}$ will be donated to a project against child labor. More specifically, the donated money will be paid to the (...)MARK Foundation, which is fighting child labour in a specific industry. For more information you can consult the official website which is shown at the end of the instructions. For legal questions we will hide the name of the product. The transfer for the donation will be made online and visible for all participants at the end of the experiment.

Producers' profits (per period):

[Unit Profit $]=[\text { Price offered }- \text { Production Cost }]^{*}[$ number of sold units $]$

Only units that are actually sold create costs.

Information for each producer after each period:

- The prices of all producers in that period,

- The quantities sold by each producer in that period,

- Each producer's profits in that period,

- The sum of own profits. 


\section{Consumers}

- In each period, every one of the six consumers must buy three units of the product.

- Each consumer has a budget of 300 ECUs to spend per period. The three units can be purchased from one, two, or all of the firms. Thus, you will be asked to indicate on the screen how many units you wish to buy from producer A, how many units from Producer B, and how many (*) units from producer $\mathrm{C}$ (has to add up to three). Purchasing decisions remain private information.

Calculation for Consumers' earnings (per period):

[Earnings] = [300] - [amount paid to producer A] - [amount paid to producer B] - [amount paid to producer $C]$

Remember that the amount paid to each producer is the price of the product that this producer has posted times the units bought from that producer.

As said, the amount corresponding to Producer C's extra production costs will be donated.

Calculation for Donations (per period):

[Donation] $=[$ number of $(*)$ units sold $] *[5]$

Information for each consumer after each period:

- Own earnings in that period,

- Own total earnings,

- The sum of donations in that period,

- The total sum of donations.

All earnings and donations in the experiment involve real money. Three ECUs of earnings will be converted into one Euro cent at the end of the experiment, so that 300 ECUs will be converted into one Euro. Additionally you will be paid the fixed show-up fee of five Euros.

If you have any questions please feel free to ask the experimenter any time!

Thank you very much for your participation! 


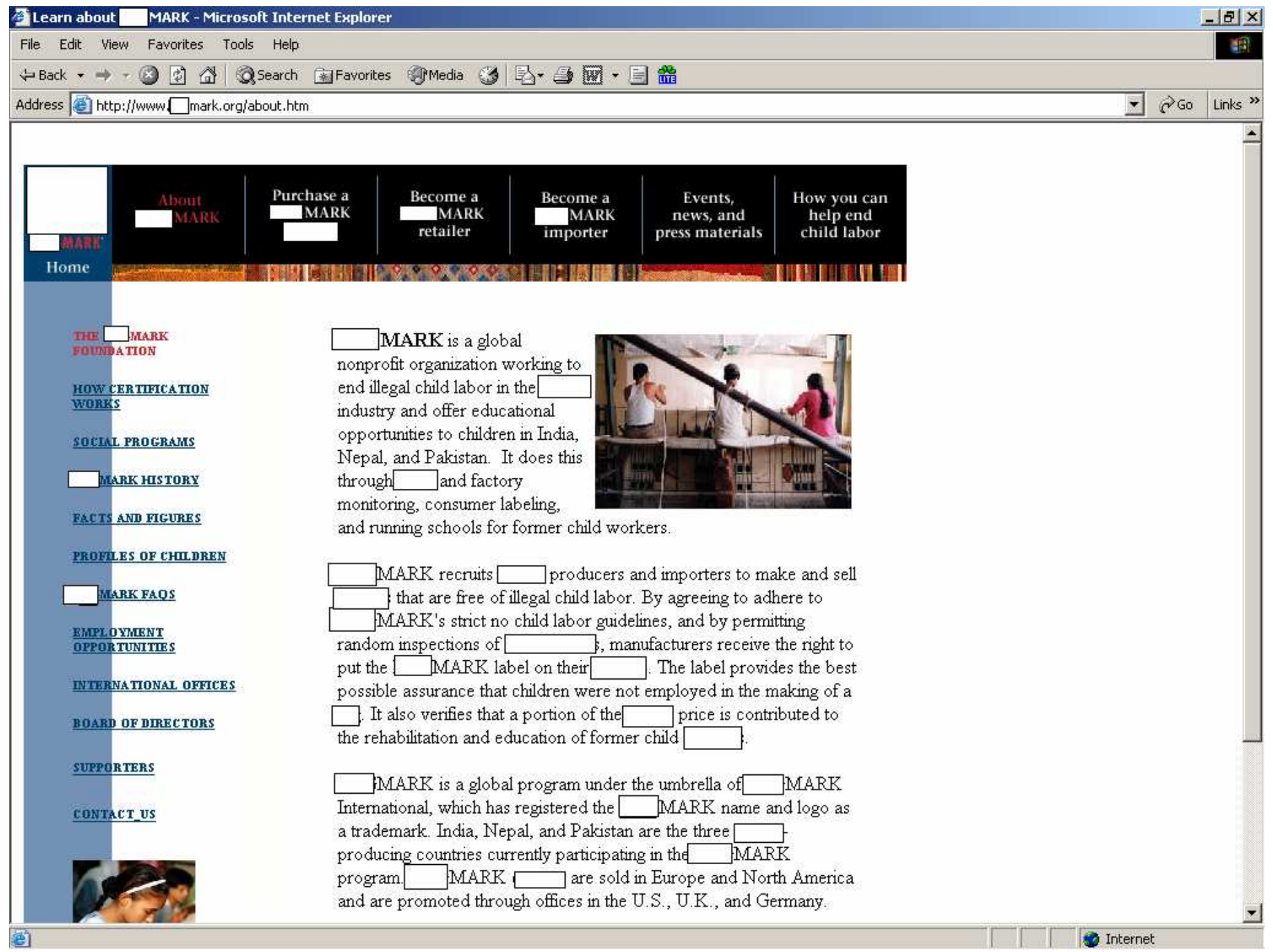

\section{(...)MARKs official webpage (12-02-2004).}

